\title{
Intestinal helminth infections amongst HIV-infected adults in Mthatha General Hospital, South Africa
}

\begin{abstract}
Authors:
Olukayode A. Adeleke ${ }^{1}$ Parimalaranie Yogeswaran ${ }^{2}$

Graham Wright $^{3}$

\section{Affiliations:}

${ }^{1}$ Department of Family Medicine, Walter Sisulu University, Mthatha, South Africa

${ }^{2}$ Department of Family Medicine and Rural Health, Walter Sisulu University,

Mthatha, South Africa

${ }^{3}$ Centre for Health Informatics Research and Development, University of Fort Hare, South Africa
\end{abstract}

\section{Correspondence to:}

Olukayode Adeleke

Email:

kay2kay001@gmail.com

Postal address:

Private Bag X1007,

Grahamstown 6140

South Africa

Dates:

Received: 29 June 2015

Accepted: 27 Sept. 2015

Published: 09 Dec. 2015

How to cite this article: Adeleke OA, Yogeswaran P Wright $\mathrm{G}$. Intestinal helminth infections amongst HIVinfected adults in Mthatha General Hospital, South Africa. Afr J Prm Health Care Fam Med. 2015;7(1), Art. \#910, 7 pages. http://dx.doi. org/10.4102/phcfm.v7i1.910

\section{Copyright:}

(C) 2015. The Authors.

Licensee: AOSIS

OpenJournals. This work is

licensed under the Creative Commons Attribution License.

\section{Read online:}

Scan this $Q R$ code with your smart phone or mobile device to read online.
Background: In South Africa, studies on the prevalence of intestinal helminth co-infection amongst HIV-infected patients as well as possible interactions between these two infections are limited.

Aim: To investigate the prevalence of intestinal helminth infestation amongst adults living with HIV or AIDS at Mthatha General Hospital.

Setting: Study participants were recruited at the outpatient department of Mthatha General Hospital, Mthatha, South Africa.

Methods: This cross-sectional study was conducted between October and December 2013 amongst consecutive consenting HIV-positive adult patients. Socio-demographic and clinical information were obtained using data collection forms and structured interviews. Stool samples were collected to investigate the presence of helminths whilst blood samples were obtained for the measurement of CD4+ T-cell count and viral load.

Results: Data were obtained on 231 participants, with a mean age of 34.9 years, a mean CD4 count of 348 cells $/ \mu \mathrm{L}$ and a mean viral load of $4.8 \log _{10}$ copies $/ \mathrm{mL}$. Intestinal helminth prevalence was $24.7 \%$, with Ascaris Lumbricoides (42.1\%) the most prevalent identified species. Statistically significant association was found between CD4 count of less than 200 cells $/ \mu \mathrm{L}$ and helminth infection $(p=0.05)$. No statistically significant association was found between intestinal helminth infection and the mean CD4 count $(p=0.79)$ or the mean viral load $(p=0.98)$.

Conclusion: A high prevalence of intestinal helminth infections was observed amongst the study population. Therefore, screening and treatment of helminths should be considered as part of the management of HIV and AIDS in primary health care.

Les infections par les helminthes intestinaux chez les adultes séropositifs à l'Hôpital Général de Mthatha, en Afrique du Sud.

Contexte: Peu d'études ont été faites en Afrique du Sud sur la prévalence de la coïnfection par les helminthes intestinaux chez les patients séropositifs ainsi que les interactions possibles entre ces deux infections.

Objectif: Etudier la prévalence d'infection par les helminthes intestinaux chez les adultes séropositifs avec le VIH ou le SIDA à l'Hôpital Général de Mthatha.

Lieu: Les participants à l'étude ont été recrutés au service de consultations externes de l’Hôpital Général de Mthatha, à Mthatha en Afrique du Sud.

Méthodes: Cette étude transversale a été faite d'octobre à décembre 2013 chez des patients séropositifs consécutifs, adultes et consentants. On a obtenu les informations sociodémographiques et cliniques au moyen de formulaires de collecte de données et d'entretiens structurés. Des échantillons de selles ont été prélevés pour déterminer la présence d'helminthes et des échantillons sanguins ont été obtenus pour mesurer le nombre de cellules T CD4+ et la charge virale.

Résultats: On a obtenu des données de 231 participants, avec un âge moyen de 34.9 ans, une moyenne de cellules CD4 de 348 cellules/ $\mu \mathrm{L}$ et une charge virale moyenne de 4.8 $\log 10$ copies $/ \mathrm{mL}$. La prévalence d'helminthes intestinaux était de $24.7 \%$, avec les Ascaris Lumbricoides (42.1\%) qui étaient les espèces les plus fréquentes. On a trouvé un lien important du point de vue statistique entre le nombre de CD4 de moins de 200 cellules/ $\mu \mathrm{L}$ et l'infection par les helminthes $(p=0.05)$. Aucune corrélation importante du point de vue statistique n'a été trouvée entre l'infection par les helminthes intestinaux et le nombre moyen de CD4 ( $p=0.79)$ ou la charge virale moyenne $(p=0.98)$.

Conclusion: On a remarqué une forte prévalence d'infections par les helminthes intestinaux chez les sujets à l'étude. Ainsi, le dépistage et le traitement des helminthes devrait faire partie de la gestion du VIH et du SIDA dans les soins de santé primaire. 


\section{Introduction}

Helminths are the most common parasitic agents of humans in Africa and other developing countries, producing a burden of disease that exceeds better-known conditions, including malaria and tuberculosis. ${ }^{1}$ Sub-Saharan Africa bears an inordinate proportion of the global HIV pandemic, being home to more than two-thirds of the estimated 35.3 million people worldwide living with HIV in 2012. ${ }^{2}$ There is significant overlaps in the geographical distribution of HIV and helminthiasis, and co-infection is highly endemic in this region. ${ }^{3}$

South Africa has the highest HIV epidemic in the world,${ }^{2}$ with an estimated $10 \%$ of the total population, approximately 5.2 million people, living with HIV or AIDS in 2013. ${ }^{4}$ A significant proportion of South Africans live in areas characterised by poverty and under-development, ${ }^{5}$ conditions that have been shown to fuel the continuing spread of HIV and helminthic infections. ${ }^{6}$ Although the national estimates of helminth prevalence are not known, data from surveys in various parts of South Africa reveal infestation levels that range between $70 \%$ and $100 \%$ in school-age children and pre-schoolers. ${ }^{5}$ For example, the prevalence of intestinal parasites amongst school children in four schools in Mthatha is reported to be $64.8 \%{ }^{7}$ In addition, helminths were identified in $21.7 \%$ of stool specimen from adults obtained from some public hospital laboratories in Kwazulu-Natal Province. ${ }^{8}$ However, data on the prevalence of intestinal parasites in the country's adult population are insufficient.

Despite the high prevalence of these two infections in SubSaharan Africa, the effect of intestinal helminths on the epidemiology of HIV infection, including the risk of HIV transmission and disease progression and management, remains uncertain. ${ }^{9}$ Studies have shown that infestation by intestinal worms adversely affects the immune response, causing immune dysfunction and diminishing the host's capacity to mount appropriate defence against infections such as tuberculosis and HIV infection. ${ }^{10,11}$ Although they vary in their biology, route of infection and developmental stages in which they exist in the human host, most helminth parasites evoke a similar immune response in the host. This entails a polarisation of CD4+ T-cells towards a Th2 phenotype, with reduced Th1-type responses, as well as immunosuppression of both worm-specific and generalised immune responses. ${ }^{12}$ Th1 cells are important in eliminating intracellular pathogens, and inflammatory responses. Th2 cells, on the other hand, target extracellular pathogens and produce cytokines, which enhance antibody production. The profound Th2 and diminished Th1 responses as well as the chronic immune activation found in patients with intestinal helminth infection have been hypothesised to lead to an increased susceptibility to HIV infection and enhanced HIV replication in helminth-infected individuals. ${ }^{12,13}$

Intestinal helminthic infection has been shown to be common amongst people living with HIV or AIDS in Africa, with prevalence ranging from $17 \%$ to $66 \%$ depending on the methods used to identify the helminths. ${ }^{5,9,14}$ However, studies conducted in several African countries have produced conflicting results regarding the impact of intestinal helminthic infection on the epidemiology of HIV. Though most authors agree on the potential theoretical deleterious immunological consequences of HIV and helminthic infection co-existing in an individual, the results from various studies evaluating the practical implication of treating intestinal helminthic infection in HIV disease progression are inconclusive. ${ }^{15}$ Whilst some studies found no effect of treatment of intestinal helminth infections on HIV disease progression, $, 1,16,17$ other authors have reported a beneficial effect, with a reduction in HIV viral load, including reduction in the risk of HIV transmission following treatment of intestinal helminthic infection. ${ }^{18,19,20}$

This study sought to explore the extent of the problem of intestinal infestation in HIV-positive adults at the Mthatha General Hospital, a district hospital located in the OR Tambo district of the Eastern Cape Province, South Africa. About $12.6 \%$ of the South African population lives in the province, the third largest and one of the poorest in the country, with the highest percentage of households living without toilet facilities. ${ }^{21}$ Although there is a paucity of data on the prevalence of HIV-helminth co-infection in the province, the endemic poverty, lack of access to clean water and poor sanitation makes it highly probable that HIV-helminth coinfection will be common in this area.

\section{Research methods and design Study design, setting and sampling strategy}

This cross-sectionalstudy was conducted within theoutpatient department of Mthatha General Hospital, Mthatha, Eastern Cape Province of South Africa. This is a district hospital that is a part of the Mthatha Academic Hospital Complex, one of the teaching complexes of the Faculty of Health Sciences, Walter Sisulu University. Consecutive patients aged 18 years and above, confirmed to be HIV-positive and HAART (Highly active antiretroviral therapy)-naïve, were enrolled between October and December 2013. They were provided with written and verbal information about the study and were required to provide written informed consent. Exclusion criteria were the presence of acute severe illnesses like pneumonia, tuberculosis or meningitis. Over a threemonth period, the population of HAART-naïve HIV-positive adults attending the outpatient department was estimated at 720 . As the prevalence of helminth infection amongst the population was unknown, this was computed as 50\%. Using a confidence level of $95 \%$ and a design effect of 1.0, a sample size of 251 was calculated using OpenEpi software..$^{22}$ None of the eligible participants declined to participate in the study.

\section{Collection, transport and processing of specimens}

Stool samples were collected according to World Health Organization (WHO) standard procedure..$^{23}$ Submitted stool 
specimens were transported in a cooler box to the department of Medical Microbiology at Walter Sisulu University within an hour of collection for microscopy. About $5 \mathrm{~mL}$ of venous blood specimen was collected in ethylenediaminetetraacetic acid (EDTA) and plasma preparation tubes, for estimation of CD4 count and plasma HIV-RNA level, immediately after collection. A pilot study was conducted amongst 20 participants who were not included in the main study. Necessary adjustments were made to the interview guide and specimen collection technique. For example, all 20 participants strongly objected to the application of transparent adhesive tape to skin around the anus to obtain ova of Enterobius vermicularis (the scotch-tape technique). The technique was omitted in the main study.

Stool specimens were processed using the formalin-ethyl acetate concentration method. An experienced medical technologist performed microscopy of the concentrated specimen, and a consultant medical microbiologist examined a random selection of the microscope slides for the purpose of quality control. Parasites were quantified based on the number of parasites seen per high microscopic power field (hpf). CD4 count was determined at the National Health Laboratory Service in Mthatha from venous blood using the Panleucogating (PLG) methodology, whilst HIV viral load was determined using COBAS $\AA$ AmpliPrep/COBAS $\AA$ TaqMan® HIV-1 Test, version 2.0.

Participants identified as having intestinal helminth infection were treated with anti-helminthic drugs according to standard practice. Participants who were eligible for antiretroviral therapy based on CD4 count were contacted and appropriately referred for treatment initiation.

\section{Statistical analysis}

Data analysis was performed using the Statistical Package for the Social Sciences (SPSS) version 21.0 (SPSS Inc., Chicago, IL, USA). Data were expressed as means \pm standard error (s.e.) of the mean or as means \pm standard deviation (s.d.) for the continuous variables and proportions (percentages) for the categorical variables. The chi-square test or Fischer's exact test was used to test the degree of association of categorical variables. Student's $t$-test was performed to assess differences between two means and analysis of variance (ANOVA) between groups. All tests were two-sided and a $p$-value of $\leq$ 0.05 was considered significant.

\section{Ethical considerations}

Ethical approval was obtained from the Human Research Committee of Walter Sisulu University (Protocol number: 005/2013). Institutional approval to conduct the research was obtained from the Eastern Cape Department of Health, Bisho.

\section{Results}

A total of 252 HIV seropositive adults were enrolled in the study. Twenty-one of these ( 6 male, 15 female) were excluded from the analysis because of incomplete data. The excluded participants were not different from the remaining participants in terms of age, gender, level of education, income, employment status, CD4 count or viral load. Of the remaining $231 \mathrm{HIV}$ seropositive patients with complete data, 72 (31\%) were male and 231 (69\%) female. The mean age of the study participants was 34.9 years (s.d. = 10.6 years), ranging from 18 years to 64 years. Other social, demographic and clinical characteristics of the participants are presented in Table 1.

Of the 231 participants, 132 (57.1\%) were unemployed, the majority of whom were dependent on various forms of social grants. The average monthly income of $53.7 \%$ of these patients was less than R1000. There was no statistically significant association between participants' age, gender, level of education or average monthly income and intestinal helminth infection. Helminth-infected participants reported

TABLE 1: Socio-demographic characteristics of the study population $(n=231)$.

\begin{tabular}{|c|c|c|c|c|c|c|c|}
\hline \multirow{2}{*}{$\begin{array}{l}\text { Characteristics } \\
\text { Age (years), mean } \pm \text { s.d. }\end{array}$} & \multicolumn{2}{|c|}{$\begin{array}{c}\text { Total participants }(n=231) \\
n(\%)\end{array}$} & \multicolumn{2}{|c|}{$\begin{array}{l}\text { Helminth-infected }(n=57) \\
n(\%)\end{array}$} & \multicolumn{2}{|c|}{$\begin{array}{l}\text { Helminth-uninfected }(n=174) \\
n(\%)\end{array}$} & ANOVA ( $p$-value) \\
\hline & \multicolumn{2}{|c|}{$34.7 \pm 10.6$} & \multicolumn{2}{|c|}{$35.4 \pm 9.7$} & \multicolumn{2}{|c|}{$34.7 \pm 10.9$} & 0.66 \\
\hline Gender & & & & & & & 0.36 \\
\hline Male & 72 & 31.2 & 15 & 26.3 & 57 & 32.8 & 0.41 \\
\hline Female & 159 & 68.8 & 42 & 73.7 & 117 & 67.2 & 0.40 \\
\hline Number of household members, mean \pm s.d. & \multicolumn{2}{|c|}{$5 \pm 4$} & \multicolumn{2}{|c|}{$6 \pm 7$} & \multicolumn{2}{|c|}{$5 \pm 3$} & 0.05 \\
\hline Employment & & & & & & & 0.09 \\
\hline Yes & 99 & 42.9 & 31 & 54.4 & 68 & 39.1 & 0.09 \\
\hline No & 132 & 57.1 & 26 & 45.6 & 106 & 60.9 & 0.09 \\
\hline Level of education & & & & & & & 0.5 \\
\hline None & 4 & 1.7 & 2 & 3.5 & 2 & 1.2 & $0.23 *$ \\
\hline Primary & 43 & 18.6 & 10 & 17.5 & 33 & 18.9 & $0.81^{*}$ \\
\hline Secondary & 146 & 63.2 & 38 & 66.7 & 108 & 62.4 & $0.53^{*}$ \\
\hline Tertiary & 38 & 16.5 & 7 & 12.3 & 31 & 17.9 & $0.32 *$ \\
\hline Average monthly income (Rand) & & & & & & & 0.51 \\
\hline$<1000$ & 125 & 53.7 & 27 & 47.4 & 98 & 56.3 & $0.27^{*}$ \\
\hline 1000 to 5000 & 86 & 37.5 & 25 & 43.8 & 61 & 35.1 & $0.26^{*}$ \\
\hline$>5000$ & 20 & 8.7 & 5 & 8.8 & 15 & 8.6 & $0.96 *$ \\
\hline
\end{tabular}

ANOVA, analysis of variance (calculated with Asymp. Sig 2-sided or Exact Sig 2-sided ANOVA); s.d., standard deviation; *, 2-tailed Z-score test 
a higher number of household members (mean $=6$ ) than their helminth-uninfected counterpart $($ mean $=5)(p=0.05)$.

As shown in Table 2, $163(70.6 \%)$ participants had access to tap water, whilst $178(77.1 \%)$ used pit latrines, mostly shared with other families. There was no statistically significant association between source of water or toilet type and helminth infection. Only $6.1 \%$ of the participants indicated that they clean their hands with soap and water after defecation, and $93.1 \%$ indicated that they wash their hands with water only. No statistically significant association was found between hand-washing practices and intestinal helminthic infection $(p=0.076)$.

Of the 231 participants whose stools were examined for intestinal parasites, helminth infection was detected in 57, representing $24.7 \%$ of the study population. Seven species of helminths were identified: Ascaris Lumbricoides (42.1\%), Trichuris trichura (5.26\%), Strongyloides stercoralis (5.26\%), Hookworm species (5.26\%) (Necator americanus, Ancylostoma duodenale), Hymenolepis nana (5.26\%), Diphylobothrium latum $(28.07 \%)$ and Fasciolopsis buski (8.8\%) (Figure 1).

TABLE 2: Sanitation-related characteristics of the study population $(n=231)$.

\begin{tabular}{|c|c|c|c|c|c|c|c|}
\hline \multirow{2}{*}{$\begin{array}{l}\text { Characteristics } \\
\text { Water source }\end{array}$} & \multicolumn{2}{|c|}{$\begin{array}{c}\text { Total participants } \\
(n=231) \\
n(\%)\end{array}$} & \multicolumn{2}{|c|}{$\begin{array}{c}\text { Helminth-infected } \\
(n=57) \\
n(\%)\end{array}$} & \multicolumn{2}{|c|}{$\begin{array}{l}\text { Helminth-uninfected } \\
(n=174) \\
n(\%)\end{array}$} & \multirow{2}{*}{$\begin{array}{r}\begin{array}{r}\text { ANOVA } \\
\text { (p-value) }\end{array} \\
0.37\end{array}$} \\
\hline & & & & & & & \\
\hline Tap & 163 & 70.6 & 39 & 68.4 & 124 & 71.3 & $0.68 *$ \\
\hline River & 48 & 20.8 & 12 & 21.1 & 36 & 20.7 & $0.95^{*}$ \\
\hline Tank & 20 & 8.7 & 6 & 10.6 & 14 & 8 & $0.56^{*}$ \\
\hline Toilet type & & & & & & & 0.45 \\
\hline Pit & 178 & 77.1 & 46 & 80.7 & 132 & 75.9 & 0.59 \\
\hline Flush & 53 & 22.9 & 11 & 19.3 & 42 & 24.1 & 0.59 \\
\hline Bucket & 0 & 0 & 0 & 0 & 0 & 0 & \\
\hline Refuse disposal & & & & & & & 0.76 \\
\hline Burning & 172 & 74.5 & 44 & 77.2 & 128 & 73.6 & $0.58^{*}$ \\
\hline $\begin{array}{l}\text { Municipal } \\
\text { collection }\end{array}$ & 58 & 25.1 & 13 & 22.8 & 45 & 25.8 & $0.64 *$ \\
\hline Others & 1 & 0.4 & 0 & 0 & 1 & 0.6 & $0.56^{*}$ \\
\hline Hand care & & & & & & & 0.20 \\
\hline None & 2 & 0.9 & 0 & 0 & 2 & 1.1 & $0.41 *$ \\
\hline $\begin{array}{l}\text { Water and } \\
\text { soap }\end{array}$ & 14 & 6.1 & 1 & 1.8 & 13 & 7.5 & $0.11 *$ \\
\hline Water only & 215 & 93.1 & 56 & 98.2 & 159 & 91.4 & $0.11^{*}$ \\
\hline
\end{tabular}

ANOVA, analysis of variance (calculated with Asymp. Sig 2-sided or Exact Sig 2-sided ANOVA), *, 2-tailed Z-score test
The CD4+ cell count of the study participants ranged widely from 3 to 1283 cells $/ \mu \mathrm{L}$, with a mean of 348 cells cells $/ \mu$ L. Sixty-nine participants $(29.9 \%)$ were severely immunosuppressed with a CD4+ cell count of less than 200 cells $/ \mu \mathrm{L}$, of whom $37(16 \%)$ had a CD4 count of less than 100 . A total of $105(45.4 \%)$ patients had a CD4+ count of more than 350 cells $/ \mu \mathrm{L}$. The mean plasma viral load for the study participants was $4.8 \log _{10}$ copies $/ \mathrm{mL}$ (Table 3). Although the participants with helminth infection had a slightly lower mean CD4 count and a slightly higher mean viral load than those with no infection, there was no statistically significant differences in the mean viral load $(p=0.98)$ or mean CD4+ cell count $(p=0.79)$ in both groups. However, low CD4 count $(<200$ cells $/ \mu \mathrm{L})$ was associated with intestinal helminthic infection. This was statistically significant $(p=0.05)$.

Apart from the seven species of intestinal helminth identified during the study, Entamoeba histolytica, a protozoan, was identified in two of the participants ( $0.9 \%$ prevalence) whilst the bacterium Escherica coli was found in 35 patients $(15.2 \%$ prevalence). Thirteen (5.5\%) of the participants had mixed infection (Table 4).

\section{Discussion}

Nearly $70 \%$ of participants in the study were female (Table 1 ), which might be an indication of low attendance of men at the outpatient department of the hospital. It has been noted that in most part of Africa, men in general seek treatment for all ailments (HIV / AIDS-related or otherwise) less often than

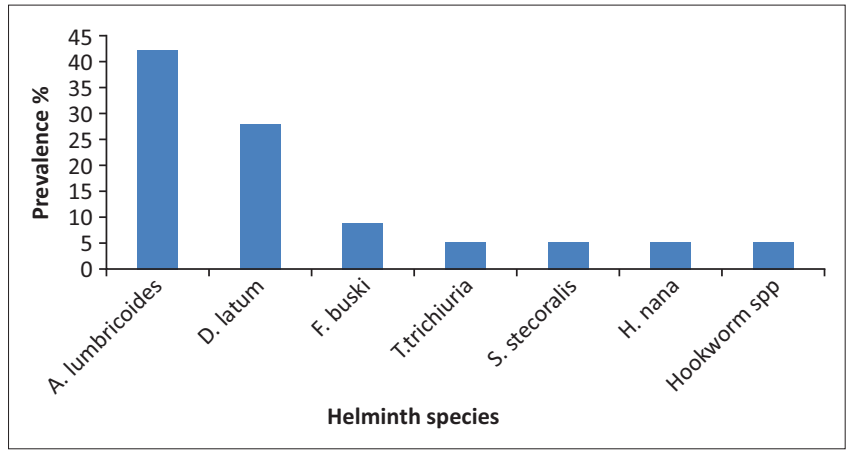

FIGURE 1: Prevalence of helminth species amongst helminth-infected participants $(n=57)$.

TABLE 3: CD4+ T-cell count and HIV viral load of the study population.

\begin{tabular}{|c|c|c|c|c|c|c|c|}
\hline $\begin{array}{l}\text { CD4+ cell count and viral load } \\
\text { CD4+ cell count category }\end{array}$ & \multicolumn{2}{|c|}{$\begin{array}{l}\text { Total participants }(n=231) \\
\qquad n(\%)\end{array}$} & \multicolumn{2}{|c|}{$\begin{array}{l}\text { Helminth-infected }(n=57) \\
n(\%)\end{array}$} & \multicolumn{2}{|c|}{$\begin{array}{l}\text { Helminth-uninfected }(n=174) \\
n(\%)\end{array}$} & $\begin{array}{c}\text { ANOVA ( } p \text {-value) } \\
0.14\end{array}$ \\
\hline$<200$ cells $/ \mu \mathrm{L}$ & 69 & 29.9 & 23 & 40.4 & 46 & 26.4 & $0.05^{*}$ \\
\hline $200-350$ cells $/ \mu \mathrm{L}$ & 57 & 24.7 & 12 & 21.0 & 45 & 25.9 & $0.47^{*}$ \\
\hline 350 cells $/ \mu \mathrm{L}$ & 105 & 45.4 & 22 & 38.6 & 83 & 47.7 & $0.23 *$ \\
\hline Log10 HIV-RNA category (copies/mL) & & & & & & & 0.35 \\
\hline$\leq 3 \log 10$ & 11 & 4.8 & 1 & 1.8 & 10 & 5.7 & - \\
\hline $3-5 \log 10$ & 120 & 51.9 & 33 & 57.9 & 87 & 50 & - \\
\hline $5 \log 10$ & 100 & 43.3 & 23 & 40.4 & 77 & 44.3 & - \\
\hline CD4+ cell count, mean ( \pm s.d.) cells $/ \mu \mathrm{L}$ & \multicolumn{2}{|c|}{$348 \pm 239$} & \multicolumn{2}{|c|}{$340 \pm 264$} & \multicolumn{2}{|c|}{$350 \pm 232$} & 0.79 \\
\hline Log10 HIV-RNA, mean ( \pm SEM) copies/mL & \multicolumn{2}{|c|}{$4.8 \pm 0.06$} & \multicolumn{2}{|c|}{$4.8 \pm 0.08$} & \multicolumn{2}{|c|}{$4.7 \pm 0.11$} & 0.98 \\
\hline
\end{tabular}

ANOVA, analysis of variance (calculated with Asymp. Sig 2-sided or Exact Sig 2-sided ANOVA).

*, 2-tailed Z-score test; s.d., standard deviation; SEM, standard error of the mean; log, logarithm. 
TABLE 4: Multiple infections amongst the study participants $(n=231)$.

\begin{tabular}{lcc}
\hline Parasites & Prevalence $(\boldsymbol{n})$ & Prevalence (\%) \\
\hline A. lumbricoides and E. coli & 4 & 1.73 \\
A. lumbricoides and F. buski & 1 & 0.43 \\
A. lumbricoides and E. histolytica & 1 & 0.43 \\
E. coli and H. nana & 5 & 2.2 \\
E. coli and D. latum & 1 & 0.43 \\
E. coli and F. buski & 1 & 0.43 \\
\hline
\end{tabular}

women. This has been attributed to the culture of 'tough' masculinity which assumes that men are more powerful and less vulnerable than women. ${ }^{24}$ It has also been shown that more women than men accessed HIV and/or AIDS care and treatment ${ }^{25}$ and were more than twice as likely to be on antiretroviral therapy (ART) than men. ${ }^{26}$

The study found that $178(77.1 \%)$ of the participants use pit latrines. This is similar to findings from a community-based survey conducted in 2008 by Mfenyana et al. ${ }^{27}$ in which only $17.9 \%$ of the households had access to a flush toilet. The low socio-economic status noted amongst the participants in this study could be because of the setting of the study. As noted by Nattrass, ${ }^{24}$ people of higher socio-economic status are less likely to use public health facilities than those of lower socioeconomic status. Consistent with the findings of Modjarrad et al. $^{28}$ as well as Mwambete et al. ${ }^{29}$ the participants' age, gender, income, level of education or occupation were not predictive of helminth status in the present study.

A statistically significant association was found between a large number of household members and helminthic infection amongst the participants. This was similar to the findings of the report by Anuar et al. ${ }^{30}$ in which increased number of household members was associated with a higher frequency of intestinal parasitic infections. Crowded living conditions in developing countries have been shown to be one of the factors that increase susceptibility to soiltransmitted helminth infection. ${ }^{31}$

Although no statistically significant association was found between hand washing and helminthic infection, the proportion of participants with helminth infection who used soap and water was smaller than those without intestinal helminth infection $(1.8 \%$ vs. $7.5 \% ; p=0.11)$. The lack of a statistically significant association in this study could be as a result of the small sample size. A review by Strunz et al. ${ }^{32}$ shows that hand washing with soap after defecation significantly reduces the risk of helminth infection. Primary care physicians and indeed all health care workers practising in this community should therefore opportunistically provide patients with information on hand-washing practices and motivate a behavioural change during every consultation.

The species of intestinal helminths detected in this study and their prevalence were similar to the findings of some of the previously published reports of helminth infection amongst adults living with HIV and AIDS in Africa. ${ }^{8,28,33}$ However, the $24.7 \%$ prevalence found in the present study was significantly lower than those from several other studies, which range from $48.7 \%$ to $66 \%{ }^{5,34}$ This difference in prevalence reported in the various studies could be because of the differences in sample sizes, setting of the studies, inclusion and exclusion criteria used in participant selection as well as the difference in the methods used in the identification of the parasites (stool microscopy with or without serology) ${ }^{5}$.

The Mthatha region of the Eastern Cape Province of South Africa has one of the highest prevalences of Taenia solium neurocysticercosis in the country. ${ }^{35}$ The absence of the eggs of tapeworms in any of the stool specimens examined is therefore noteworthy, considering the high prevalence of neurocysticercosis in the community. The absence could be attributed to the small sample size or could be a result of HIV enteropathy, which affects the colonisation of the intestinal tract by parasites. ${ }^{36}$ Larger studies should be conducted to explore the relationship between the prevalence of T. solium and HIV infection in this community.

The mean CD4 count of the study population was 348 cells / $\mu \mathrm{L}$. The relatively lower CD4 count of the participants in this study could be attributed to the fact that this was a facility-based study, involving individuals who are more immunosuppressed than those found in the community. In this study, 69 (29.9\%) of the participants were considerably immunosuppressed with a CD4 count of less than 200.

Consistent with the findings of Mwambete et al. ${ }^{29}$ a statistically significant association was observed in the present study between a CD4 count less than 200 cells $/ \mu \mathrm{L}$ and helminth infection (Table 3). This is in contrast to the report by Walson et al. ${ }^{14}$ who noted an increased prevalence of intestinal helminth infection amongst patients with higher CD4 counts. The correlation of helminth infection with higher CD4 count found by Walson et al. ${ }^{14}$ could be attributed to the inclusion in the study of only individuals with CD4 counts greater than 250 cells $/ \mu \mathrm{L}$ and without WHO Stage 3 or 4 disease. This represents patients with less severe immune suppression than those in the present study.

No statistically significant difference was found between the mean CD4+ cell count $(p=0.79)$ of the helminth coinfected participants compared to the helminth-uninfected. This is similar to findings from similar studies conducted in Uganda, ${ }^{17}$ South Africa ${ }^{5}$ and Ethiopia. ${ }^{37}$ In addition, no statistically significant association was observed between intestinal helminth infection and viral load in this study ( $p=0.98)$, similar to the findings of Modjarrad et al. ${ }^{38}$ and Hosseinipour et al. ${ }^{9}$ but contrary to the findings of others. ${ }^{5,37}$

The lack of association between CD4 count, viral load and intestinal helminth infection in the present study could be attributed to the small sample size as well as possible underestimation of the presence of intestinal helminth because stool microscopy was used as the sole method of diagnosing helminthiasis. It could also be attributed to the difference in the prevalence of the various helminth species identified in this study compared to those identified in studies where association has been found between CD4 count or viral 
load and helminthic infection. As Mkhize-Kwitshana et al. ${ }^{5}$ have argued, diagnosis of helminthiasis based on stool microscopy alone could lead to a wrong classification of infection or non-infection and could affect the evaluation of the immunological effect of helminth co-infection on HIV and AIDS. Further studies that incorporate monitoring of markers of immune activation are necessary in order to provide a better understanding of the HIV-helminth relationship.

\section{Limitations}

As a cross-sectional survey, this study is useful in generating hypothesis but cannot show any causal or risk relationships. The use of a hospital-based population in this study was not representative of the adult population in Mthatha. Moreover, the study population may not be representative of all patients at the outpatient department because of the use of convenient sampling.

HIV-negative individuals were not included in this study to serve as a comparison group. As a result of this, comparative inferences cannot be made on the prevalence of helminth infections across populations of differing HIV status. Only one stool specimen was collected from each participant and helminth detection was based only on the use of light microscopy. These could have led to an under-estimation of the prevalence of helminthiasis.

\section{Recommendation}

It is recommended that larger community-based studies be conducted to determine the extent of intestinal helminth coinfection amongst people living with HIV or AIDS. Future studies should include HIV-negative comparison groups and be appropriately designed to explore several aspects of HIV-helminth interactions, including the effect of the various helminth species as well as multiple infections on HIV disease. Diagnosis of intestinal helminth infections in such studies should include, in addition to microscopy, parasite serology and molecular diagnostic techniques.

\section{Conclusion}

The study revealed that intestinal helminth infection was relatively common amongst the study population, with $24.7 \%$ prevalence. Helminthiasis was diagnosed in this study using a simple and cost-effective technique of stool microscopy, but the prevalence of intestinal helminth could actually be higher if other methods of identification (such as serology) were combined with microscopy.

Intestinal helminthic infections are known to be associated with high morbidity, adversely affecting the host's general health and nutritional status. ${ }^{39}$ In HIV-positive patients, this represents an additional burden on already compromised hosts. In this study, no statistically significant association was found between intestinal helminth infection and markers of HIV disease progression; however, intestinal helminth infection was found to be significantly associated with lower CD4 count $(<200$ cells $/ \mu \mathrm{L})$. Routine anti-helminth treatment should therefore be included as part of patients' comprehensive care, at least amongst this group of patients.

\section{Acknowledgements}

The authors thank Mr Eric Nombekela, Dr T. Apalata and Prof. S. Vasaikar of the Microbiology Department, Water Sisulu University for their assistance in the identification of intestinal parasites in stool specimens.

\section{Competing interests}

The authors declare that they have no financial or personal relationship(s) that may have inappropriately influenced them in writing this article.

\section{Authors' contributions}

O.A.A. (Walter Sisulu University) was the primary researcher. He designed the study, collected the specimen and analyse the data to fulfil the requirements for the degree of Master of Medicine (MMed) in Family Medicine at Walter Sisulu University. He wrote the article in a publishable format. P.Y. (Walter Sisulu University) was the study leader. She took part in conceptualising and designing the study. She provided appropriate and invaluable contributions towards the completion of the project and the final draft of the manuscript. G.W. (University of Fort Hare) was a cosupervisor and contributed to the study design and sampling procedure. He provided guidance towards the completion of the project and documentation.

\section{References}

1. Hotez PJ, Brindley PJ, Bethony JM, King CH, Pearc EJ, Jacobson J. Helminth infections: The great neglected tropical diseases. J Clin Invest. 2008;118(4):13111321. PMID: 18382743 , http://dx.doi.org/10.1172/JCI34261

2. Joint United Nations Programme on HIV/AIDS (UNAIDS). Global report: UNAIDS report on the global AIDS epidemic 2013 [page on the Internet]. Geneva: UNAIDS 2013 [cited 2014 Jan 3]. Available from: http://www.unaids.org/en/resources/ campaigns/globalreport2013/globalreport

3. Webb EL, Ekii AO, Pala P. Epidemiology and immunology of helminth-HIV interactions. Curr Opin HIV AIDS. 2012;7(3):245-253. PMID: 22411451, http:// dx.doi.org/10.1097/COH.0b013e32835210cd

4. Statistics South Africa. Mid-year population estimates, 2013 [page on the Internet]. Pretoria: Statistics South Africa; 2013 [cited 2013 Dec 28]. Available from: http://beta2.statssa.gov.za/publications/P0302/P03022013.pdf

5. Mkhize-Kwitshana ZL, Taylor M, Jooste P, Mabaso ML, Walzl G. The influence of different helminth infection phenotypes on immune responses against HIV in co-
infected adults in South Africa. BMC Infect Dis. 2011;11(1):273. PMID: 21999928, http://dx.doi.org/10.1186/1471-2334-11-273

6. Fincham JE, Markus MB, Adams VJ. Could control of soil-transmitted helminthic infection influence the HIV/AIDS pandemic. Acta Trop. 2003;86(2):315-333. PMID: 12745148, http://dx.doi.org/10.1016/S0001-706X(03)00063-9

7. Nxasana $\mathrm{N}$, Baba K, Bhat $\mathrm{V}$, Vasaikar S. Prevalence of intestinal parasites in primary school children of Mthatha, Eastern Cape Province, South Africa. Ann Med Healt Sci Res. 2014;13(3):511-516. PMID: 24380000, http://dx.doi.org/10.4103/21419248.122064

8. Kwitshana ZL, Tsoka JM, Mabaso ML. Intestinal parasitic infections in adult patients in KwaZulu-Natal. S Afri Med J. 2008;98(9):709. PMID: 19113052.

9. Hosseinipour MC, Napravnik S, Joaki G, et al. HIV and parasitic infection and the effect of treatment among adult outpatients in Malawi. J Infect Dis. 2007;195(9):1278-1282. PMID: 17396996, http://dx.doi.org/10.1086/513274

10. Bentwich Z, Teicher CL, Borkow G. The helminth HIV connection: Time to act. AIDS. 2008;22(13):1611-1614. PMID: 18670220, http://dx.doi.org/10.1097/ QAD.0b013e32830a506e

11. Da'dara AA, Harn DA. Elimination of helminth infection restores HIV-1C vaccine-specific $T$ cell responses independent of helminth-induced IL-10. Vaccine. 2010;28(5):1310-1317. PMID: 19941988, http://dx.doi.org/10.1016/j vaccine.2009.11.019 
12. Bourke CD, Maizels RM, Mutapi F. Acquired immune heterogeneity and its sources in human helminth infection. Parasitology. 2011:138(2):139-159. PMID: 20946693, http://dx.doi.org/10.1017/S0031182010001216

13. Borkow G, Bentwich Z. Chronic immune activation associated with chronic helminthic and human immunodeficiency virus infections: Role of hyporesponsiveness and anergy. Clin Microbiol Rev. 2004;17(4):1012-1030. PMID: 15489359, http://dx.doi.org/10.1128/CMR.17.4.1012-1030.2004

14. Walson JL, Stewart BT, Sangaré L, et al. Prevalence and correlates of helminth co-infection in Kenyan HIV-1 infected adults. PLoS Negl Trop Dis. 2010;4(3):e644. PMID: 20361031, http://dx.doi.org/10.1371/journal.pntd.0000644

15. Sangaré LR, Herrin BR, John-Stewart G, Walson JL. Species-specific treatment effects of helminth/HIV-1 co-infection: A systematic review and meta-analysis. Parasitology. 2011;138(Special Issue 12):1546-1558. PMID: 21729353, http:// dx.doi.org/10.1017/S0031182011000357

16. Elliott AM, Mawa PA, Joseph S, et al. Associations between helminth infection and CD4+ T cell count, viral load and cytokine responses in HIV-1-infected Ugandan adults. Trans R Soc Trop Med Hyg. 2003;97(1):103-108. PMID: 12886815, http:// dx.doi.org/10.1016/S0035-9203(03)90040-X

17. Brown $M$, Kizza $M$, Watera $C$, et al. Helminth infection is not associated with faster progression of HIV disease in coinfected adults in Uganda. J Infect Dis. 2004;190(10):1869-1879. PMID: 15499545.

18. Walson JL, Herrin BR, John-Stewart G. Deworming helminth co-infected individuals for delaying HIV disease progression. Cochrane Database Syst Rev. 2009;3(3). PMID: 19588389, http://dx.doi.org/10.1002/14651858.CD006419.pub3

19. Modjarrad K, Vermund SH. Effect of treating co-infections on HIV-1 viral load: A systematic review. Lancet Infect Dis. 2010;10(7):455-463. PMID: 20610327 , A systematic review. Lancet Infect Dis. 2010;10(7):4
$\mathrm{http}: / / \mathrm{dx}$.doi.org/10.1016/S1473-3099(10)70093-1

20. Gallagher M, Malhotra I, Mungai PL, et al. The effects of maternal helminth and malaria infections on mother-to-child HIV transmission. AIDS. 2005;19(16):18491855. PMID: 16227793, http://dx.doi.org/10.1097/01.aids.0000189846.90946.5d

21. Statistics South Africa. General household survey, 2012 [page on the Internet] Pretoria: Statistics South Africa; 2013 [cited 2013 Dec 29]. Available from: http:// www.statssa.gov.za/publications/P0318/P0318August2012.pdf

22. Open Source Epidemiologic Statistics for Public Health (OpenEpi). Sample size for frequency in a population [page on the Internet]. 2013 [cited 2013 Feb 10] Available from: http://www.openepi.com/SampleSize/SSPropor.htm

23. World Health Organization (WHO). Basic laboratory methods in medical parasitology [page on the Internet]. Geneva: WHO; 1991 [cited 2011 Aug 20] Available from: http://whqlibdoc.who.int/publications/9241544104_(part1).pdf

24. Nattrass N. Gender and access to antiretroviral treatment in South Africa. Fem Econ. 2008;14(4):19-36. http://dx.doi.org/10.1080/13545700802266452

25. Coetzee D, Hildebrand K, Boulle A, et al. Outcomes after two years of providing antiretroviral treatment in Khayelitsha, South Africa. AIDS. 2004;18(6):887-895. PMID: 15060436.

26. Bärnighausen T, Tanser F, Herbst K, Mutevedzi T, Mossong J, Newell ML. Structural barriers to antiretroviral treatment: A study using population-based CD4 cell count and linked antiretroviral treatment programme data. Lancet. 2013;382:S5. http://dx.doi.org/10.1016/S0140-6736(13)62253-9
27. Mfenyana K, Griffin M, Yogeswaran P, et al. Socio-economic inequalities as a predictor of health in South Africa: The Yenza cross-sectional study. S Afr Med J. 2008;96(4):323-330. PMID: 16670806.

28. Modjarrad K, Zulu I, Redden DT, Njobvu L, Freedman DO, Vermund SH. Prevalence and predictors of intestinal helminth infections among human immunodeficiency virus type 1-infected adults in an urban African setting. Am J Trop Med Hyg. 2005;73(4):777-782. PMID: 16222025.

29. Mwambete KD, Justin-Temu M, Peter S. Prevalence and management of intestinal helminthiasis among HIV-infected patients at Muhimbili National Hospital. J Int Assoc Physicians AIDS Care 2010;9(3):150-156. PMID: 20530468, http://dx.doi. org/10.1177/1545109710368138

30. Anuar TS, Salleh FM, Moktar N. Soil-transmitted helminth infections and associated risk factors in three Orang Asli tribes in peninsular Malaysia. Sci Rep. 2014;4:1-7. PMID: 24525479, http://dx.doi.org/10.1038/srep04101

31. De Silva NR, Brooker S, Hotez PJ, Montresor A, Engels D, Savioli L. Soiltransmitted helminth infections: Updating the global picture. Trends Parasitol. 2003;19(12):547-551. PMID: 14642761, http://dx.doi.org/10.1016/j. pt.2003.10.002

32. Strunz EC, Addiss DG, Stocks ME, Ogden S, Utzinger J, Freeman MC. Water, sanitation, hygiene, and soil-transmitted helminth infection: A systematic review and meta-analysis. PLoS Med. 2014;11(3):e1001620. PMID: 24667810, http:// dx.doi.org/10.1371/journal.pmed.1001620

33. Idindili B. Challenges of continuum of HIV/AIDS care and treatment in Tanzania: The effects of parasites co-infections, HIV clinical manifestations, and adherence to antiretroviral therapy [doctoral dissertation] Basel: University of Basel; 2012 [cited 2014 Apr 26]. Available from: http://edoc.unibas.ch/22092/1/PhD_ dissertation_Boniphace_Idindili.pdf

34. Hailemariam G, Kassu A, Abebe G, et al. Intestinal parasitic infections in HIV/AIDS and HIV seronegative individuals in a teaching hospital, Ethiopia. Jpn J Infect Dis. 2004;57(2):41-43. PMID: 15118206.

35. Foyaca-Sibat $\mathrm{H}$, Del Rio-Romero I. Prevalence of epilepsy in an endemic area for neurocysticercosis in South Africa. Internet J Neurol. 2008;9(1):8-18.

36. Babatunde SK, Salami AK, Fabiyi JP, Agbede OO, Desalu OO. Prevalence of intestinal parasitic infestation in HIV seropositive and seronegative patients in Ilorin, Nigeria. Ann Afr Med. 2010;9(3). 123-128. PMID: 20710101, http://dx.doi. org/10.4103/1596-3519.68356

37. Mulu A, Maier M, Liebert UG. Deworming of intestinal helminths reduces HIV-1 subtype C virem Dis. 2013;17(10):e897-e901. PMID: 23688549, http://dx.doi.org/10.1016/j. ijid.2013.03.022

38. Modjarrad K, Zulu I, Redden DT, et al. Treatment of intestinal helminths does not reduce plasma concentrations of HIV-1 RNA in coinfected Zambian adults. J Infect Dis. 2005b;192(7):1277-1283. PMID: 16136473, http://dx.doi. org $/ 10.1086 / 444543$

39. Hotez PJ, Bundy D, Beegle K, et al. Helminth infections: Soil-transmitted helminth infections and schistosomiasis [chapter on the Internet]. In: Jamison DT, Breman JG, Measham AR, et al., editors. Disease control priorities in developing countries. New York: Oxford University Press; 2006 [cited 2012 Nov 21]; p. 467-82. Available from: http://www.dcp-3.org/sites/default/files/dcp2/DCP24.pdf 